\title{
Nutrient index, microbial activity and soil quality depleted under sugarcane mono-sequencing in Indian subtropics
}

\author{
S. R. Singh ${ }^{1}$, S. Singh ${ }^{2}$, Tapendra Srivastava ${ }^{3}$, M. Tripathi ${ }^{2}$, R. Dohare ${ }^{2}$, Ram Verma ${ }^{4}$, \\ Poonam Yadav ${ }^{2}$, and R. Singh ${ }^{2}$ \\ ${ }^{1}$ ICAR-Indian Institute of Sugarcane Research, Lucknow \\ ${ }^{2}$ Indian Institute of Sugarcane Research \\ ${ }^{3}$ ICAR- Indian Institute of Sugarcane Research, P.O. Dilkusha, Raebareli Road, Lucknow \\ 226002 , India \\ ${ }^{4}$ Indian Institute of Sugarcane Research, Lucknow - 226 002, Uttar Pradesh, India
}

October 20, 2021

\begin{abstract}
Sugarcane mono-sequencing is one of the prominent systems of Uttar Pradesh but wide variations in cane yields are the main cause of concern across the cane producing zones. Hence, 131, 198 and 122 composite soil samples $(0-20 \mathrm{~cm}$ depth) were taken from cane producing Eastern zone (EZ), Central zone (CZ) and Western zone (WZ) of Uttar Pradesh, respectively to assess the causes of yield variations and impact of sugarcane mono-sequencing on nutrient index (NI), microbial activity and soil quality. Sugarcane mono-sequencing depleted soil organic carbon (SOC), available nitrogen (Na), potassium (Ka), sulphur (Sa) and $\mathrm{Zn}$ as 48.9, 98.2, 39.0, 43.3 and $26.4 \%$ soil samples falls in low categories, respectively. However, soil degradation aggregated more in EZ soils due to acute deficiency of macro-nutrients as well as high content of $\mathrm{Cu}$, Fe and $\mathrm{Mn}$ in low-lying areas. Total microbial counts, microbial biomass of $\mathrm{C}$ and $\mathrm{N}$, basal soil respiration, acid and alkaline phosphatase were highest in WZ, but $\mathrm{Na}, \mathrm{Pa}, \mathrm{Ka}$, Sa, FDA, $\beta$-glucosidase and urease activity was greater in CZ soils. As a result, NI was greater in CZ (2.19) followed EZ (1.98) and WZ (1.97), but soil quality index (SQI) was found in the order of CZ $(0.795)>$ WZ $(0.785)>$ EZ $(0.708)$. The sensitivity index $(\mathrm{S})$ was lowest in CZ soils (1.420) indicated that WZ (1.810) and EZ (1.915) soils are more preferable and sensitive to perturbations and management practices. Na was the most vital indicator for sugarcane production followed by SOC, AZO and Sa.
\end{abstract}

Nutrient index, microbial activity and soil quality depleted under sugarcane mono-sequencing in Indian subtropics

S.R. Singh ${ }^{*}$, S. N. Singh, T. K. Srivastawa, M. K. Tripathi, R.S. Dohare, R.R. Verma, Poonam Yadav and R.K. Singh

Indian Institute of Sugarcane Research Lucknow, India-226002

\section{Abstract}

Sugarcane mono-sequencing is one of the prominent systems of Uttar Pradesh but wide variations in cane yields are the main cause of concern across the cane producing zones. Hence, this study was undertaken to assess the causes of yield variations and impact of long-term sugarcane mono-sequencing on nutrient index (NI), microbial activity and soil quality. About 131, 198 and 122 composite soil samples $(0-20 \mathrm{~cm}$ depth) were taken from cane producing Eastern zone (EZ), Central zone (CZ) and Western zone (WZ) of Uttar Pradesh, respectively and analyzed. Long-term sugarcane mono-sequencing depleted soil organic carbon (SOC), available nitrogen $\left(\mathrm{N}_{\mathrm{a}}\right)$, potassium $\left(\mathrm{K}_{\mathrm{a}}\right)$, sulphur $\left(\mathrm{S}_{\mathrm{a}}\right)$ and $\mathrm{Zn}$ as 48.9, 98.2, 39.0, 43.3 and $26.4 \%$ 
soil samples falls in low categories, respectively. However, soil degradation aggregated more in EZ soils due to acute deficiency of macro-nutrients as well as high content of $\mathrm{Cu}, \mathrm{Fe}$ and $\mathrm{Mn}$ in low-lying areas. Total microbial counts (TCB, TCA, AZO), microbial biomass of carbon and nitrogen, basal soil respiration, acid and alkaline phosphatase were highest in WZ but $\mathrm{N}_{\mathrm{a}}, \mathrm{P}_{\mathrm{a}}, \mathrm{K}_{\mathrm{a}}, \mathrm{S}_{\mathrm{a}}, \mathrm{FDA}, \beta$-glucosidase and urease activity was greater in CZ soils. As a result, NI was more in CZ (2.19) followed EZ (1.98) and WZ (1.97), but soil quality index (SQI) was found in the order of CZ (0.795) > WZ (0.785) > EZ (0.708). The sensitivity index was lowest in CZ soils (1.420) followed by WZ (1.810) and EZ (1.915) indicated that WZ and EZ soils are more preferable and sensitive to perturbations and management practices. $\mathrm{N}_{\mathrm{a}}$ was the most vital soil quality indicator (contributed 25.7, 26.9 and 23.7\% towards SQI development in EZ, CZ and WZ, respectively) followed by SOC, AZO and $\mathrm{S}_{\mathrm{a}}$. Under nutrient deficient zone, targeted yield equations may be useful for improving NI, SQI and sensitivity index to achieve sustainable cane productivity and soil quality.

Key words: Sugarcane monocropping, Nutrient index, Microbial activity, Minimum data set, Soil quality index.

\section{Abbreviations:}

ACP: acid phosphatase activity, ALP: alkaline phosphatase activity, AZO-Aztobacter counts, $\mathrm{N}_{\mathrm{a}}$ : available nitrogen, $\mathrm{P}_{\mathrm{a}}$ : available phosphorus, $\mathrm{K}_{\mathrm{a}}$ : available $\mathrm{K}, \mathrm{S}_{\mathrm{a}}$ : available sulphur, $\beta$-glu: $\beta$-glucosidase, BSR: basal soil respiration. CZ: central zone, DAP: diammoinum phosphate, DHA: dehydrogenase activity, EC: electrical conductivity, EZ: eastern zone, FDA: fluorescein diacetate hydrolytic activity, MBC: microbial biomass carbon, MBN: microbial biomass nitrogen, MDS: minimum data set, NI: Nutrient index, SOC: soil organic carbon, SQI: soil quality index, $S$ : sensitivity index, TC: total carbon, TCA: total culturable actinomycetes counts, TCB: total culturable bacterial counts, TCF: total culturable fungal counts, TYE: targeted yield equations, WZ: western zone.

\section{INTRODUCTION}

India is the second largest sugarcane producer in the world with $18.7 \%$ of world's production during 2017 after Brazil, which is the largest (37.0\%) producer of the world (FAO, 2019). The increasing demand of foodstuffs, animal feed, chemicals and industry are the major causes of sugarcane expansion. Lisboa et al. (2011) stated that increasing demand of bio-ethanol is the key driver of this quick increase. Since, it used as a sustainable bio-energy sources, reduces emission of greenhouse gases (GHGs), minimize unpredictability related to volatility of fossil fuel prices (Black et al., 2012), and endowing a fixed income source for farmers. Thus, sugarcane paramount a key role in Indian economy as 50 million farmers' and 5.0 lakhs skilled and unskilled workers are engaged in its production and processing (Krishnakant et al., 2015).

In India, sugarcane cultivated $45 \%$ and $55 \%$ of the total area in tropical and sub-tropical conditions, respectively but vice-versa in its production. Uttar Pradesh is the key sugarcane producing province under subtropics has largest area $(2.234 \mathrm{~m} \mathrm{ha})$, production $(177.06 \mathrm{~m} \mathrm{t})$ and average productivity $\left(79.26 \mathrm{t} \mathrm{ha}^{-1}\right)$ during 2017-18 (Cooperative sugar, 2021). As many as 30 district, in which Muzaffarnagar, Meerut, Bijnor, Moradabad and Saharanpur, districts in western zone (WZ), Bareilly, Shahjahanpur, Lakhimpur-Kheri and Sitapur districts in central zone (CZ) and Kushinagar, Gonda, Balrampur, Basti, Bahraich and Maharajganj in eastern zone (EZ) are considered as the main cane producing district of Uttar Pradesh. WZ is considered as cane heart land of the state due to highest cane production in India. Though, wide yield variations existed across the cane production zones of Uttar Pradesh despite having similar soil type (alluvial soils) might be due to variations in nutrient management and edaphic factor. Rahman and Bee (2019) observed 82.9, 72.0 and $66.9 \mathrm{Mg} \mathrm{ha}^{-1}$ and Cooperative sugar (2021) reported 90.7, 86.8 and $77.8 \mathrm{Mg}^{-1}$ cane productivity of Muzaffarnagar, Lakhimpur-kheri, and Kushinagar district during 2016-2017 and 2019-20, respectively. Indeed, cane productivity has been increased significantly during the decade due to inducting high yielding variety and advance management practices, but yield variation remains is the cause of concern in sub-tropical region (Uperti and Singh, 2017). Yet, the right causes of cane yield variations are not confirmed. Albeit, there are various reasons including increasing compactness, degrading soil structure, nutrient losses through erosion, declining SOC, and increasing multi-nutrient deficiency (Hartemink, 1998). 
In addition, low-lying area affected with floods, surface runoff and water logging during monsoon can be a major cause to suffer production and productivity of sugarcane in EZ (Rahman and Bee, 2019). Imbalance fertilization over the years can be another factor for variations in cane yield, nutrient index and soil quality. Because, sugarcane is a heavy nutrient feeder crop required $150-350 \mathrm{~kg} \mathrm{~N} ; 60-100 \mathrm{~kg} \mathrm{P}_{2} \mathrm{O}_{5}$, and $60-120 \mathrm{~kg}$ $\mathrm{K}_{2} \mathrm{O}$ ha $^{-1}$ annually depending upon planting time, growing condition and nutrient status in soil. However, sugarcane growers largely using 150:60:60 kg N, $\mathrm{P}_{2} \mathrm{O}_{5}$ and $\mathrm{K}_{2} \mathrm{O}_{\text {ha }}{ }^{-1}$ year $^{-1}$ across the sub-tropical zone from the decades despite changes of fertility gradient (from medium to low or very low categories of nutrients). Contrary to that, sugarcane removed about 208, 53 and $280 \mathrm{~kg} \mathrm{~N}, \mathrm{P}$, and $\mathrm{K} \mathrm{ha}^{-1}$ year $^{-1}$ for producing 100 $\mathrm{Mg} \mathrm{ha}{ }^{-1}$ cane yields (Shukla et al., 2017). Sugarcane mono-cropping over the years depleted 53, 56, 84 and $86 \% \mathrm{SOM}$, total $\mathrm{N}$, Olsen $\mathrm{P}$ and exchangeable $\mathrm{K}$, respectively than the virgin land $(0-30 \mathrm{~cm}$ depth). Chi et al. (2017) also suggested that prolonged sugarcane cropping has detrimental effects on soil fertility, but deterioration depends on soil types, surface runoff and water logging (Satiro et al., 2017). Heavy mechanization in sugarcane also caused adverse impact on soil compaction notably in top soils. Consequently, reduce soil aeration, soil resistance and infiltration rates and increases runoff and soil erosion in Brazil (Macedo, 2007). Thus, cumulative effects of these factors affect microbial life in soils (i.e. bacterial, fungal, actinomycetes, and nematodes counts) (Hartemink, 2008). Holt \& Mayer (1998) observed that long-term sugarcane cultivation had low enzymes' activity than natural habitats and pasture. Although, it varied with management practices such as unfertilized/fertilized, burnt/green harvesting, trash removal/trash mulching and tillage level employed (Yadav et al., 2009; Stirling et al., 2010; Castioni et al., 2018).

Soil quality may be defined as the capacity of a soil to function within ecosystem boundaries to sustain biological productivity, maintain environmental quality, and promote plant and animal health (Doran and Parkin, 1994a). Recently, it utilized by various researchers as a tool for assessing the suitability of management practices implies in a soil, and indices have been developed to grade and compare soil conditions over time and or between different locations (Nortcliff, 2002). Various methods such as soil management assessment framework (Masto et al., 2007) , Fuzzy association rule (Yue-Ju et al., 2010), dynamic variability of soil quality methods (Larson \& Pierce, 1994), nutrient index (Amara et al., 2017), soil health cards and test kit (Ditxler \& Tugei, 2002) have been employed by researchers for soil quality assessment. Among these methods, soil quality index has been most extensively applied due to its quantitative flexibility and suitability for different types of soil and its coordination among the physical, chemical and biological attributes. Hence, soil quality indices are using at large scale to assess the impact of long-term management practices in particular crop production on the soil at a district; regional and provincial scale (Gong et al., 2015). Soil quality markers are vital component that incorporate soil function, and reflect environmental differences at large scale liable to influence soil quality. Though, lacking in consensus on which soil marker is useful for soil quality monitoring. For instance, Rahmanipour et al. (2014) had chosen soil erodibility, chromium and cobalt contents as quality indicators to assess soil quality, but were not found in other research. Liu et al. (2015) included some biological indicators like as acid phosphatase, and total counts of bacteria and AM fungi in minimum data set. However, soil $\mathrm{pH}, \mathrm{P}_{\mathrm{a}}, \mathrm{K}_{\mathrm{a}}$, soil structure and SOC were considered as ideal soil quality indicators for the sugarcane production in Brazil (Cherubin et al., 2016). deFreitas et al. (2018) also reported that total sand, clay, micro-porosity, magnesium, calcium, soil $\mathrm{pH}$, and organic matter considered as a sensitive soil quality indicators for sugarcane and native forest grown in northeastern São Paulo state, Brazil.

Certain soil environments have been shown to produce ultra-high sugarcane yields (i.e., $>100 \mathrm{t} \mathrm{ha} \mathrm{h}^{-1}$ ). Although, it is unaware to which extent soil physical, chemical and biological properties contribute to create yield differences between the area under ultra-high yields and average yields within the same soil order (Bigott et al., 2019). Although, the study was meager to assess causes of yield variation and long-term impact of sugarcane mono-cropping on nutrient index, microbial activity and soil quality across the cane producing zones of Uttar Pradesh. Hence, this study was undertaken to (i) assess the chemical and biological properties of soil on different cane producing zones of Uttar Pradesh, (ii) evaluate the effects of soil attributes on nutrient index, soil quality and sensitivity measurement differ among the high, average and lower yielding areas and (iii) suggest the doses of balance fertilizer for different cane producing zones of Uttar Pradesh. 


\section{MATERIALS AND METHODS}

\subsection{Study site, soil sampling and nutrient analysis}

The current study was undertaken in key cane producing districts of Kushinagar (Eastern zone-EZ), Sitapur and Lakhimpur-kheri (Central zone-CZ), and Muzaffarnagar (Western zone-WZ) of Uttar Pradesh Province, India. The study site comprises in alluvial soil (Inceptisol) covered about $10.7 \times 10^{4} \mathrm{~km}^{2}$ (Fig. 1) which spreads across the subtropical zone with dry winter and hot summer. The average annual temperature and precipitation ranged from 24.2 to $31.0^{\circ} \mathrm{C}$ and 736 to $1000 \mathrm{~mm}$, respectively (Table 1). About 131, 198 and 122 soil samples were taken through AMS auger $(0-20 \mathrm{~cm}$ depth) on standing sugarcane crops from eastern zone (EZ), central zone (CZ) and western zone (WZ) during November-December, 2017, respectively (Table 1). Random sampling was followed, in which five samples were collected from one location, and pooled for making composite sample. Immediately after collection, moist samples were divided in two parts. In which, one parts packed separately in sterilized polythene bags and stored in ice-packed box, and finally stored in $-20^{\circ} \mathrm{C}$ at laboratory for microbial study. Simultaneously, $100 \mathrm{~g}$ fresh moist samples were taken separately in moisture box for the determination of moisture content. The remaining portion of soil sample was packed in separate polythene bags, brought to the laboratory, and processed for analyzing physical and chemical attributes. Soil $\mathrm{pH}, \mathrm{EC}, \mathrm{N}_{\mathrm{a}}, \mathrm{P}_{\mathrm{a}}, \mathrm{K}_{\mathrm{a}}$ and $\mathrm{S}_{\mathrm{a}}$ were analyzed as per protocol proposed by Jackson (1973). The SOC was determined by TOC analyzers (Multi N/C-2100S-Analytic-Jena), while as Zn, Cu, Fe and Mn were through atomic absorption spectrophotometer (Z2300, Hitachi Science and Technology) as per the protocol of USDA (1996).

The total culturable count of bacteria (TCB), fungi (TCF), actinomycetes (TCA) and Azotobacter ( AZO) were estimated by using nutrient agar media having $50 \mathrm{mg} \mathrm{L}^{-1}$ cyclohexamide (Parkinson et al., 1971), Rose Bengal chloramphenicol agar media containing $100 \mathrm{mg} \mathrm{L}^{-1}$ chloramphenicol (Martin, 1950), Ken Knight and Ashbys mannitol (Subba Rao, 1977), respectively through serial dilution and plate counting techniques. The chloroform fumigation-extraction method (Vance et al., 1987) was applied for determination of microbial biomass carbon (MBC), whereas, microbial biomass nitrogen (MBN) was analyzed by chloroform-fumigationincubation and distillation method (Jenkinson \& Powlson, 1976). The basal soil respiration (BSR) was analyzed through barium chloride method as suggested by Anderson (1983). The dehydrogenase activity (DHA), fluorescein diacetate hydrolytic (FDA), urease and $\beta$-glucosidase ( $\beta$-glu), acid (ACP) and alkaline phosphatase activities (ALP) were determined as per the methods of Alef \& Nannipieri (1995).

\subsection{Soil quality assessment}

The method used to determine soil quality index following by four steps: (i) setting the goal, (ii) picking minimum data set (MDS) of indicators which depict the best soil function, (iii) scoring the MDS indicators, and (iv) the integration of an indicator score into a relative soil quality index (Masto et al., 2007). Cane productivity was considered as the goal due to variations in different cane producing zones. A total of 25 soil attributes were analyzed using principal component analysis (PCA) for selecting as representative MDS (Andrews et al., 2002). PCs that had high eigenvalues and variables with greater factor loading were pondered as the best delineated attributes. Hence, PCs with eigenvalues $>1$ and those illustrated at least $5 \%$ variations in the data were examined (Bregda et al., 2000). The factor loading of each variable in a particular $\mathrm{PC}$ represents the contribution of that variant to the composition of the PC. Highly weighted variable were categories as per the absolute values existed within $10 \%$ of the highest factor loading. Correlation coefficient was employed among the indicators for selecting ideal indicator if any variable was redundant as more than one variable was retained within a single PC and hence, eliminated from the minimum data set (MDS). In terms of soil function, the indicators were put in order depending on whether a higher value was considered as 'good' or 'bad'. Indicators like $\mathrm{N}_{\mathrm{a}}, \mathrm{P}_{\mathrm{a}}, \mathrm{K}_{\mathrm{a}}, \mathrm{S}_{\mathrm{a}}, \mathrm{Fe}, \mathrm{Zn}, \mathrm{ALP}$ and BSR in the MDS were considered "good" and were scored as "more is better'. However, Fe content was pondered "good" as existed in the optimum range, hence scored as 'optimum is better'. A value between 0 and 1 is used as a standard scoring function for transmission and normalized of each indicator (Fig. S1) which were calculated by using non-linear scoring function (NLSF): $\operatorname{NLSF}(\mathrm{Y})=1 /\left[1+\mathrm{e}^{-\mathrm{b}(\mathrm{x}-\mathrm{A})}\right]$. 
where, ' $\mathrm{x}$ ' is value of soil attributes, 'A' the baseline or value of soil property where score equal to 0.5 and 'b' is slope.

Once indicator transformed based on soil functions, the MDS attributes for each observation were weighted by applying the PCA outcome. Each PC incites a certain amount (\%) of the variation in the total data set. This percentage divided by the total percentage of variance explained by all PCs with eigenvectors $>1$, given the weighted factor for variants selected under a given PC. Then the weighted MDS variables scores were summed up for each observation using the following equation as suggested by Li et al. (2013): SQI $=\sum_{i=1}^{n} \mathrm{Wi} \times \mathrm{Si}$

Where, 'Wi' is denoting weighing value of each indicators; 'Si' is the indicator score; ' $\mathrm{n}$ ' is the number of indicators in the MDS.

The SQ indexing methods were also measured by employing sensitivity analysis as suggested by Masto et al. (2008): Sensitivity (?) $=\mathrm{SQI}_{(\max )} / \mathrm{SQI}_{(\min )}$, where $\mathrm{SQI}_{(\max )}$ and $\mathrm{SQI}_{(\min )}$ are the maximum and minimum SQI observed under each cane producing zones of Uttar Pradesh. The higher value of sensitivity is more preferable and sensitive to perturbations and management practices.

\subsection{Computation of mineral fertilizers}

Since, wide variations in soil fertility across the cane producing zones, a workable targeted yield equation (TYE) for plant $\left(\mathrm{FN}=7.37 \mathrm{~T}-1.95 \mathrm{SN}, \mathrm{FP}_{2} \mathrm{O}_{5}=0.96 \mathrm{~T}-2.21 \mathrm{SP}\right.$ and $\left.\mathrm{FK}_{2} \mathrm{O}=3.36 \mathrm{~T}-0.83 \mathrm{SK}\right)$ and ratoon crop $\left(\mathrm{FN}=5.91 \mathrm{~T}-1.83 \mathrm{SN}, \mathrm{FP}_{2} \mathrm{O}_{5}=0.64 \mathrm{~T}-1.85 \mathrm{SP}\right.$ and $\left.\mathrm{FK}_{2} \mathrm{O}=2.33 \mathrm{~T}-0.60 \mathrm{SK}\right)$ were used for balance fertilization in different cane producing zones by employing initial soil test value and defined targeted cane yield. A wonder sugarcane variety (Co 0238) which covered larger area (alluvial soil) in Uttar Pradesh was used for developing TYE during 2016-17 and 2017-18 by considering nutrient required to achieve per $\mathrm{Mg}$ cane yield, utilization efficiencies of nutrients available in soil and those applied through inorganic fertilizers were considered for developing TYE (Ramamoorthy \& Velayutham 1971).

where, $\mathrm{FN}, \mathrm{FP}_{2} \mathrm{O}_{5}$ and $\mathrm{FK}_{2} \mathrm{O}$ are mineral fertilizers $\mathrm{N}, \mathrm{P}_{2} \mathrm{O}_{5}$ and $\mathrm{K}_{2} \mathrm{O}\left(\mathrm{kg} \mathrm{ha}^{-1}\right)$; SN, SP and $\mathrm{SK}$ are initial soil test values estimated before planting. To make symmetry, $\mathrm{P}_{2} \mathrm{O}_{5}$ and $\mathrm{K}_{2} \mathrm{O}$ were converted into $\mathrm{P}$ and $\mathrm{K}$ by applying factor 2.29 and 1.20, respectively. T-targeted cane yield $\left(\mathrm{Mg} \mathrm{ha}^{-1}\right) . \mathrm{N}_{2} \mathrm{P}_{2} \mathrm{O}_{5}$ and $\mathrm{K}_{2} \mathrm{O}$ fertilizers were calculated on the basis of above equations for balance fertilization.

\subsection{Statistical analysis}

The SPSS16.0 (2001) software was used for descriptive statistical and correlation analysis. Pearson product moment correlation test was applied to assess the relationship among the soil variables. The sampling adequacy of individual and set variables were computed by using Kaiser-Meyer-Olkin test $(>0.5)$ and Bartlett's test of sphericity $(P<0.05)$. The PCA was computed to derive the most identical soil indicators. To assess the long-term sugarcane monocropping impact, two approaches were employed. First, the percentage alter in the individual soil fertility parameters under different cane producing zones of Uttar Pradesh to assess whether soil fertility parameters were declines or improve. Second, Nutrient Index (NI) was calculated using parameters following the Ramamurthy \& Bajaj (1969) approach. A Nutrient Index is an estimate of the \% distribution of soil samples across categories: low, medium and high classes of nutrient status as per the soil test value interpretation (Amara et al., 2017) by using: Nutrient Index $(\mathrm{NI})=\left[\left(\mathrm{N}_{\mathrm{L}} \times 1\right)+\left(\mathrm{N}_{\mathrm{M}} \times 2\right)+\right.$ $\left.\left(\mathrm{N}_{\mathrm{H}} \times 3\right) / \mathrm{N}_{\mathrm{T}}\right]$

where, ' $\mathrm{N}_{\mathrm{L}}$ ', ' $\mathrm{N}_{\mathrm{M}}$ ' and ' $\mathrm{N}_{\mathrm{H}}$ ' typify the number of samples falling in the low, medium and high class of nutrient status, respectively, and ' $\mathrm{N}_{\mathrm{T}}$ ' is the total number of samples analyzed across the cane producing zones of Uttar Pradesh. The NI levels were computed according to low $(<1.67)$, medium $(1.67-2.33)$ and high $(>2.33)$ category. Maps showing geographical locations of the soil sampling site were created through Google map.

\section{RESULT}

\subsection{Soil characteristics of different sugarcane zones}


Sampling adequacy of 131, 198 and 122 soil samples collected from different cane producing zones of Uttar Pradesh were measured using Kaiser-Meyer-Olkin and Bartlett's test to assess the goodness of its analysis. The KMO value of EZ, CZ and WZ were greater than $\mathrm{p}>0.50$ evinced that the sampling was adequate (Table S1). Moisture content was the most crucial factor, ranged between 11.6 to $29.8 \%$ across the cane producing zones of Uttar Pradesh. The highest moisture content was retained in EZ soils followed by WZ and CZ. Value of soil $\mathrm{pH}$ varied from 6.12-8.80, being the highest in EZ followed by $\mathrm{CZ}$ and WZ, while EC value existed in normal range across the cane growing zones. Although, no definite trends were observed in $\mathrm{SOC}, \mathrm{N}_{\mathrm{a}}, \mathrm{P}_{\mathrm{a}}$, $\mathrm{K}_{\mathrm{a}}$ and $\mathrm{S}_{\mathrm{a}}$, but were ranged between 2.0-7.90 $\mathrm{g} \mathrm{kg}^{-1}, 100.3-290.9 \mathrm{~kg} \mathrm{ha}^{-1}, 3.35-45.3 \mathrm{~kg} \mathrm{ha}^{-1}$ and 2.48-28.1 mg $\mathrm{kg}^{-1}$, respectively. The highest mean values of $\mathrm{N}_{\mathrm{a}}, \mathrm{P}_{\mathrm{a}}$ and $\mathrm{K}_{\mathrm{a}}$ in CZ, while as SOC and $\mathrm{S}_{\mathrm{a}}$ were in EZ and WZ soils, respectively. Reversely, EZ soils contained highest values of $\mathrm{Zn}, \mathrm{Cu}, \mathrm{Fe}$ and $\mathrm{Mn}$ than $\mathrm{CZ}$ and WZ. The lowest value of $\mathrm{Zn}, \mathrm{Cu}, \mathrm{Fe}$ and $\mathrm{Mn}$ were recorded in WZ soils (Table 2).

The MBC, MBN and BSR were ranged between 68.4-498.7 $\mu \mathrm{g} \mathrm{C} \mathrm{g}-1,0.60-4.17 \mathrm{~m} \mathrm{~g} \mathrm{NH}_{3}-\mathrm{N} \mathrm{kg}^{-1} \mathrm{~d}^{-1}$ and 7.06-42.0 mg CO $\mathrm{CO}_{2}-\mathrm{Cg}^{-1} \mathrm{~d}^{-1}$ across the cane producing zones of Uttar Pradesh (Table 3). MBC, MBN and BSR were recorded maximum in WZ, which was 49.3 and $72.9 \%, 74.6$ and $32.0 \%$ and 14.5 and $22.9 \%$ more than EZ and CZ soils, respectively. Similarly, the highest mean value of TCB, TCA and AZO were counted in WZ soils, but TCF noted maximum in EZ that was 3.48 and $83.8 \%$ greater than CZ and WZ, respectively. Reversely, FDA, $\beta$-glucosidase and urease activities were highest in CZ soils, and the lowest in EZ, while DHA was greater in EZ (Table 3). ACP and ALP were highest in WZ followed by CZ and EZ.

\subsection{Nutrient index of different sugarcane zones}

The NI ranking was used to assess the long-term sugarcane mono-cropping impact on nutrient pattern changes (Table 4). The NI of SOC altered from medium to low category $(<1.67)$ in CZ and WZ, but EZ maintained at medium level (1.69). Lower NI $(<1.67)$ of $\mathrm{N}_{\mathrm{a}}$ was recorded entire the cane producing zones under the study, being the highest was in CZ (1.04) than that of EZ and WZ (1.00). NI of $\mathrm{P}_{\mathrm{a}}$ and $\mathrm{K}_{\mathrm{a}}$ was falls under medium category (1.67-2.33) in $\mathrm{CZ}$ and $\mathrm{WZ}$, whereas lower level was existed in EZ. The medium NI category of $\mathrm{S}_{\mathrm{a}}$ was maintained only in WZ but EZ (1.51) and CZ (1.38) showed $<1.67$. The NI of Zn was recorded in medium level which ranged between 1.67-2.33 in EZ and CZ, whereas WZ soils had lower NI levels of $\mathrm{Zn}$ (1.66). The NI level of $\mathrm{Cu}, \mathrm{Fe}$ and $\mathrm{Mn}$ were highest (>2.33) across the cane producing zones of Uttar Pradesh, except NI of Fe was maintained at medium level in WZ. Overall, the higher mean NI value was observed in CZ (2.19) followed by EZ (1.98) and WZ (1.97).

\subsection{Soil quality}

For productivity goal, a total of 25 soil attributes of 131, 198 and 122 soil samples were collected from EZ, CZ and WZ were analyzed using PCA. Seven PCs from each EZ and CZ were pondered, while eight PCs were identified in WZ that showed $74.9,68.3$ and $69.3 \%$ of the cumulative variation, respectively. Variables which consisted high factor loading, eigenvalue $>1$ and explained at least $5 \%$ of the variation from each PC in EZ, CZ and WZ were mull as best representative attributes. The variability explained under each PC in $\mathrm{EZ}, \mathrm{CZ}$ and $\mathrm{WZ}$ were varied (Tables 5). In EZ, $\mathrm{N}_{\mathrm{a}}, \mathrm{K}_{\mathrm{a}}, \mathrm{Fe}, \mathrm{SOC}, \mathrm{P}_{\mathrm{a}}, \mathrm{S}_{\mathrm{a}}$ and $\mathrm{AZO}$ were considered as best representative under MDS from PC1, PC2, PC3, PC4, PC5, PC6 and PC7 due to high factor loading, respectively. In $\mathrm{CZ}, \mathrm{N}_{\mathrm{a}}, \mathrm{AZO}, \mathrm{ALP}, \mathrm{SOC}, \mathrm{Fe}, \mathrm{S}_{\mathrm{a}}$ and BSR were highly weighted attributes in PC1, PC2, PC3, PC4, PC5, PC6 and PC7, respectively. In WZ, $\mathrm{N}_{\mathrm{a}}$, SOC, AZO, $\mathrm{K}_{\mathrm{a}}, \mathrm{ALP}, \mathrm{S}_{\mathrm{a}}$, BSR and Zn had high factor loading value in $\mathrm{PC} 1, \mathrm{PC} 2, \mathrm{PC} 3, \mathrm{PC} 4, \mathrm{PC} 5, \mathrm{PC} 6, \mathrm{PC} 7$ and $\mathrm{PC} 8$, respectively, hence retained as the final MDS for indexing procedure of SQI. After completing the MDS process, the shape of the expected response i.e., "more is better" soil function was decided to all the variables retained in EZ, CZ and WZ, except for Fe content which was adjudged as "optimum is better" soil function (Table 6). The thresholds values were allotted taking into account the site specific characteristics and management goal. Weights were assigned to the MDS indicator using the PCA outcomes (Table 6) which were equal to the percentage of total variance explained by the PC. The single weighted variables were hold in each PC, hence, the full weight equal of each PC was entrusted to each variable. Thus, each of the MDS parameters was changed to a value between 0 and 1 . Soil quality index was computed by sum up of the entire weighted variable retained under MDS as follows: 
SQI for eastern zone (EZ)

$\left[0.237 S_{\mathrm{Na}}+0.135 S_{\mathrm{Ka}}+0.107 S_{\mathrm{Fe}}+0.829 S_{\mathrm{SOC}}+0.0722 S_{\mathrm{Pa}}+0.0632 S_{\mathrm{Sa}}+0.0513 S_{\mathrm{AZO}}\right] / 0.75$

$\mathrm{SQI}=0.316 S_{\mathrm{Na}}+0.180 S_{\mathrm{Ka}}+0.143 S_{\mathrm{Ka}}+0.111 S_{\mathrm{SOC}}+0.0963 S_{\mathrm{Pa}}+0.0844 S_{\mathrm{Sa}}+0.0684 S_{\mathrm{AZO}}$

SQI for central zone $(\mathrm{CZ})$

$\mathrm{SQI}=\left[0.212 S_{\mathrm{Na}}+0.127 S_{\mathrm{AZO}}+0.0936 S_{\mathrm{ALP}}+0.0724 S_{\mathrm{SOC}}+0.0639 S_{\mathrm{Fe}}+0.0628 S_{\mathrm{Sa}}+0.0508 S_{\mathrm{BSR}}\right] / 0.68$

$\mathrm{SQI}=0.312 S_{\mathrm{Na}}+0.187 S_{\mathrm{AZO}}+0.138 S_{\mathrm{ALP}}+0.106 S_{\mathrm{SOC}}+0.0940 S_{\mathrm{Fe}}+0.0923 S_{\mathrm{Sa}}+0.0747 S_{\mathrm{BSR}}$

SQI for western zone (WZ)

$\mathrm{SQI}=\left[0.194 S_{\mathrm{Na}}+0.108 S_{\mathrm{SOC}}+0.0858 S_{\mathrm{AZO}}+0.0736 S_{\mathrm{Ka}}+0.0651 S_{\mathrm{ALP}}+0.0581 S_{\mathrm{Sa}}+0.0568 S_{\mathrm{BSR}}+0.0511 S\right.$ $\mathrm{Zn}] / 0.69$

$\mathrm{SQI}=0.281 S_{\mathrm{Na}}+0.157 S_{\mathrm{SOC}}+0.1248 S_{\mathrm{AZO}}+0.107 S_{\mathrm{Ka}}+0.0904 S_{\mathrm{ALP}}+0.0840 S_{\mathrm{Sa}}+0.0823 S_{\mathrm{BSR}}+0.0741 S_{\mathrm{Zn}}$

The SQI varied from 0.469 to 0.972 across the cane producing zones of Uttar Pradesh with mean values ranged from 0.708 to 0.795 . The SQI followed in the descending order of $\mathrm{CZ}(0.795)>\mathrm{WZ}(0.785)>\mathrm{EZ}$ (0.708) soils with coefficient variations of $11.5,6.83$ and11.2, respectively. The contribution among the MDS retained in EZ, CZ and WZ towards the soil quality development fluctuated, but $\mathrm{N}_{\mathrm{a}}$ showed closely comparable contribution across the cane producing zones of Uttar Pradesh (Table 7). The sensitivity index was lowest in CZ (1.42) followed by WZ (1.81) and EZ (1.94).

\subsection{Recommendation of balanced mineral fertilizers for different cane producing zones}

The doses of mineral fertilizers for achieving $100 \mathrm{Mg}$ cane yield ha ${ }^{-1}$ varied in different cane producing zones of Uttar Pradesh (Table 8). Based on TYE, the greater nutrient will be required for plant crop than ratoon compared to recommended dose of mineral fertilizers (RDF) across the cane producing zones. The highest $\mathrm{N}$ fertilizers required in WZ soils followed by EZ and $\mathrm{CZ}$, while EZ soils required greater amount of $\mathrm{P}$ and K followed by WZ and CZ for both plant and ratoon crops. Nitrogen doses varied from 211-541, 170-344 and $260-474 \mathrm{~kg} \mathrm{~N}$ ha-1 with mean values of 348,261 and $386 \mathrm{~kg} \mathrm{~N} \mathrm{ha}^{-1}$ for plant crop, whereas 98-407, 59-222 and 144-344 $\mathrm{kg} \mathrm{N}$ ha $^{-1}$ with mean value of 226,144 and $262 \mathrm{~kg} \mathrm{~N}^{-1}$ for ratoon crop in EZ, CZ and WZ, respectively. Phosphorus doses ranged from 6-89,-4-70 and 23-88 with mean value of 73,33 and 55 $\mathrm{kg} \mathrm{P}_{2} \mathrm{O}_{5} \mathrm{ha}^{-1}$ for plant crop, whereas slight lower $\mathrm{P}$ doses will be require for ratoon crop which ranged from $-12-58,-20-42$ and 3-58 $\mathrm{kg} \mathrm{P}_{2} \mathrm{O}_{5} \mathrm{ha}^{-1}$ with mean value of 45, 11 and $29 \mathrm{~kg} \mathrm{P}_{2} \mathrm{O}_{5} \mathrm{ha}^{-1}$ in EZ, $\mathrm{CZ}$ and WZ, respectively. For plant crop, the doses of $\mathrm{K}$ varied from 98-302, 83-241 and 62-277 $\mathrm{kg} \mathrm{K}_{2} \mathrm{O}$ ha ${ }^{-1}$ with mean value of 262, 152 and $211 \mathrm{~kg} \mathrm{~K}_{2} \mathrm{O} \mathrm{ha}^{-1}$, whereas 61-209, 50-164 and 35-191 kg K $\mathrm{O}_{2} \mathrm{ha}^{-1}$ with mean value of 180,100 and $142 \mathrm{~kg} \mathrm{~K}_{2} \mathrm{O}$ ha $^{-1}$ required for ratoon crop in different cane producing zones of Uttar Pradesh, respectively.

\section{DISCUSSION}

\subsection{Physical and chemical properties of soils}

Sugarcane mono-sequencing over the years degraded agro-ecosystem due to alteration of physical, chemical and biological properties of soil, and destroy self-adjustment capability of the ecosystem (Lin et al., 2012). Magarey (1996); Pankhurst et al., (2003) and Lin et al. (2012) revealed that several factors like as imbalance fertilization and excessive use of agrochemicals, tillage, mechanical harvesting and haul-out with heavy machinery are accountable for the degrading physical, chemical and biological attributes of soil under longterm sugarcane monoculture. The MC, soil $\mathrm{pH}, \mathrm{SOC}$, and micro-nutrients $(\mathrm{Zn}, \mathrm{Cu}, \mathrm{Fe}$ and $\mathrm{Mn}$ ) were higher in EZ soils than CZ and WZ due to low-lying areas which hold more moisture content. Quietly higher soil pH in EZ could be related to accumulate more basic cations in upper surface of soil (Jenny, 1941). The SOC was increased by 14.1 and $11.8 \%$ in EZ soils than CZ and WZ, respectively due to more organic matter added through newly developed roots in low lying areas. Hidaka et al. (2007) also suggested that newly developed cane roots shared more in dry matter accumulation under flooding condition. Reversely, 
decreased SOC in WZ and CZ soils than EZ was associated with excess management practices followed in soil preparation (chiseling, plowing and harrowing) resulting exposed soil micro-aggregates favours $\mathrm{C}$ mineralization, and increasing $\mathrm{CO}_{2}$ emissions (Moscatelli et al., 2007). Naranjo et al. (2006) supported our results as $17 \%$ decline in total soil carbon over the 30 years of sugarcane monoculture compared to natural land uses (Naranjo et al., 2006).

The low $\mathrm{N}_{\mathrm{a}}, \mathrm{P}_{\mathrm{a}}, \mathrm{K}_{\mathrm{a}}$ and $\mathrm{S}_{\mathrm{a}}$ were in EZ soil might be due to lower doses of mineral fertilizers were applied even though recommended dose of mineral fertilizers (150, 60 and $60 \mathrm{~kg} \mathrm{~N}, \mathrm{P}_{2} \mathrm{O}_{5}$ and $\mathrm{K}_{2} \mathrm{O} \mathrm{ha}^{-1}$ ). It mismatches between nutrient applied and removal (205, 53 and $280 \mathrm{~kg} \mathrm{~N}, \mathrm{P}$ and $\mathrm{K}$ for the production of $100 \mathrm{Mg}$ cane yield $\mathrm{ha}^{-1}$ ) over the decades caused nutrient imbalances (Shukla et al., 2017). Moreover, low lying area led to decrease $\mathrm{N}_{\mathrm{a}}$ through leaching and denitrification. Similarly, $\mathrm{P}_{\mathrm{a}}$ also decreased in EZ soil through surface overflow and greater soil pH. Hart, Quin, \& Nguyen, (2004) reported P loss via runoff, which ranged between 0.7 and $42 \%$ of the fertilizer applied. Hence, low $\mathrm{P}_{\mathrm{a}}$ in EZ soil related to higher soil $\mathrm{pH}$ and moisture content as significant negative correlation existed among them (Table $3 \mathrm{~S}$ ). The lowest $\mathrm{S}_{\mathrm{a}}$ in EZ due to gradual removal from the soil as leaching, overflow and through plant removal, but it could not applied as mineral fertilizers regularly (Shukla \& Lal, 2004). The low-lying areas that waterlogged during monsoon season caused favorable condition to reduce $\mathrm{Cu}^{+}, \mathrm{Fe}^{2+}$ and $\mathrm{Mn}^{+}$resulting to increase its availability in EZ sols. Contrary to that, decrease $\mathrm{Zn}, \mathrm{Cu}, \mathrm{Fe}$ and $\mathrm{Mn}$ availability in WZ soil due to greater redox potential liable to converted $\mathrm{Cu}^{+}$to $\mathrm{Cu}^{+2}, \mathrm{Fe}^{+2}$ to $\mathrm{Fe}^{+3}$ and $\mathrm{Mn}^{+2}$ to $\mathrm{Mn}^{+4}$ (Pavanasasivam \& Axley, 1980). Further, harvesting more cane yield in WZ zone thereby reduced its availability due to its greater mining through crop removal.

\subsection{Microbial and enzymatic activity}

Microbial counts (TCB, TCA and AZO), MBC, MBC and BSR were highest in WZ soil could be related to producing greater root biomass and its exudates thereby producing higher cane yield as $25 \%$ extra $\mathrm{N}$ fertilizers applied over the recommended dose than $\mathrm{CZ}$ and $\mathrm{EZ}$ due to low initial $\mathrm{N}$ status $(<280 \mathrm{~kg} \mathrm{~N}$ $\left.h^{-1}\right)$. As a result, microbial counts accelerated their growth by enhancing nutrient availability which used as carbon substrate (Meena et al., 2014; Shukla et al., 2020). The greater microbial counts, root biomass and its exudates liable to enhanced $\mathrm{MBC}$ and $\mathrm{MBN}$ as are mull to the living part of organic matter, and augmenting BSR by accelerating microbial residues decomposition process (Vinhal-Freitas et al., 2017). Though, the excess $\mathrm{N}$ fertilization had negative correlation with microbial activity, but lower $\mathrm{N}_{\mathrm{a}}(<280 \mathrm{~kg} \mathrm{~N}$ $h^{-1}$ ) across the cane producing zones of Uttar Pradesh (98.2\% soil samples) had positive effects on microbial growth. The neutral soil $\mathrm{pH}$ and greater availability of macro and micro-nutrients favorable for fungal counts resulted more in CZ soils. Our results supported by Graham \& Haynes (2005) and Vieira-Megda et al. (2015) who suggested that moderate and high $\mathrm{N}$ fertilization induced microbial population in sugarcane thereby increased MBC and MBN. The lowest MBC, MBN and BSR in EZ soils coupled with N, P, K and S deficiency affected synthesis of microbial biomass. In addition, higher micronutrient caused adverse effect on microbial accounts as our results also showed significant negative correlations to these nutrients with TCB, TCA and AZO (Table S3).

Soil enzymes are integral parts of soil fertility as it played crucial role in nutrient recycling, decomposition and nutrient fixation. The FDA, $\beta$-glucosidase and urease activities were more in CZ soils could be due to lower $\mathrm{pH}$ value, and greater macronutrient and microbial counts led to enhance their activity as these factor played vital role in microbial and enzyme activation. Also, $\mathrm{N}$ is a crucial edaphic factor essentially required in large quantity for achieving higher cane productivity, and microbial growth, since it used as substrate and energy source during trash decomposition due to high $\mathrm{C}: \mathrm{N}$ ratio (108:1). Hence, FDA, $\beta$-glucosidase and urease had significant positive correlation with soil $\mathrm{pH}$ and $\mathrm{N}_{\mathrm{a}}$ (Table 3S). Reversely, lowest enzyme activities in EZ soils associated to higher soil $\mathrm{pH}$, moisture content and lower microbial activities thereby inhibited synthesis and secretion of these enzymes (Zhang et al., 2014). The change in osmotic potential and specific ion toxicities (Rietz \& Haynes, 2003) linked to lower urease activity in EZ soils. However, higher moisture content augmented DHA as active dehydrogenases utilized both $\mathrm{O}_{2}$ and other compounds as terminal electron acceptors, although, anaerobic microorganisms liable to produce most of the dehydrogenases (Brzezińska et 
al., 2001). In addition, DHA showed metabolic ability of soil proportional to SOC, as a result significant positive relation was existed between SOC and DHA. Association between DHA and total microbial activity is not always evident notably in complex soil system, wherein microbial counts actively involved in the degradation of various organic compounds that are highly diverse (Salazar et al., 2011). Hence, a significant negative correlation of DHA with microbial counts was found in our study (Table S3). ACP and ALP was highest in WZ soil could be connected to higher counts of bacteria, and MBC and FDA (Table 3) thereby induces the synthesis and secretion of phosphomonoesterases enzymes. Our results clearly indicated that ACP had significant positive correlation with TCB, MBC and FDA (Table 3S).

\subsection{Soil quality}

The causes for low or higher cane yield across the cane producing zones of Uttar Pradesh varied, but changes in nutrient index, microbial activity and soil quality might be the main reasons (Kang et al., 2005). About 25 physical, chemical and biological soil attributes were used to set up a minimum data set (MDS) based on higher factor loading value sort out by using PCA. These attributes have been used by several researchers (Bhaduri \& Purakayastha, 2014; Masto et al., 2007; Qi et al., 2009) for selecting potential indicators to assess soil quality as each could affect crop productivity. Among them, $\mathrm{N}_{\mathrm{a}}$, SOC, AZO and $\mathrm{S}_{\mathrm{a}}$ were emerges as common quality indicators across the cane producing zones, but their contribution towards SQI development were fluctuated which depend upon the management factors, site specific characters and ecological factors. $\mathrm{N}_{\mathrm{a}}$ is one of the most crucial factors for achieving sustainable cane productivity, but it is most limiting nutrient across the cane producing zones as $98.2 \%$ soil samples showed low categories $\left(<280 \mathrm{~kg} \mathrm{~N} \mathrm{ha}^{-1}\right)$ (Brady \& Well, 2000). $\mathrm{N}_{\mathrm{a}}$ contributes 13.5 and $4.67 \%$ more in CZ soils than WZ and EZ towards SQI development linked to greater $\mathrm{N}_{\mathrm{a}}, \mathrm{P}_{\mathrm{a}}$ and $\mathrm{K}_{\mathrm{a}}, \mathrm{AZO}$ counts, urease activity and normal $\mathrm{pH}$ range. Our results are in line with the results of Landell et al. (2003) and Otto et al. (2017) as significant strong positive correlation of $\mathrm{N}_{\mathrm{a}}$ with $\mathrm{P}_{\mathrm{a}}$, $\mathrm{K}_{\mathrm{a}}, \mathrm{AZO}, \beta$-glucosidase and urease activity (Table 3S). SOC was retained as quality indicators across the cane producing zones due to its greater factor loading values than other soil variables. In addition, SOC is the most extensively used as a soil quality indicator owing to its multifunction role including filtering and buffering, physical stability and support, nutrient recycling and as primary food source for microorganisms (Carter, 2002; Gregorich et al., 1994). The lowest SOC contribution in WZ soils due to $57.4 \%$ soil samples falls in low category than EZ $(32.8 \%)$ and CZ (56.6\%). The contribution of Azotobacter counts were 5.01, 14.1 and $9.11 \%$ towards the SQI development in EZ, CZ and WZ, respectively. Fluctuations in their contribution related to changes in edaphic variables that alter by following management practices, and ecological condition. The lowest Azotobacter contribution in EZ soil linked to low $\mathrm{O}_{2}$ availability in low-lying areas as highly aerobic in nature and very sensitive at low $\mathrm{O}_{2}$ levels, hence affected their growth and activity. Esmailpour et al. (2013) suggest that Azotobacter is free living- $\mathrm{N}_{2}$ fixer that have the ability to fix $20 \mathrm{~kg} \mathrm{~N} \mathrm{ha}^{-1}$ per $\mathrm{y}^{-1}$ or per season thereby synthesis their cell protein notably in N-deficient soil, which mineralized after the death of their cells (Wani et al., 2016). Fe was pondered as soil quality indicators in EZ and CZ cane producing zones which contributed 8.70 and $6.50 \%$ towards SQI development, respectively. Because, EZ soils prone to water-logging resulting decreasing redox potential resulting excess electron changes from $\mathrm{Fe}^{3+}$ and $\mathrm{Mn}^{4+}$ to $\mathrm{Fe}^{2+}$ and $\mathrm{Mn}^{2+}$ (Singh \& Setter, 2017). $\mathrm{K}_{\mathrm{a}}$ was also retained as highly weighted factor in EZ and WZ, but contributed more in EZ soils (11.6\%) than WZ (6.98\%) in SQI development owing to 87.8 and $28.7 \%$ soil samples falls under low $\mathrm{K}$ category $\left(<120 \mathrm{~kg} \mathrm{ha}^{-1}\right)$, respectively. Imbalance fertilization and excess $\mathrm{K}$ removal from soil through surface runoff, leaching and plants acquisition are the causes of more K-deficiency in EZ than WZ soil. However, it could not surface as quality indicators in CZ soils due to more K availability (Alemayehu, 2010; Shukla et al., 2009; Kingston, 2014). Available P was retained in EZ, whereas ALP were chosen in CZ and WZ as quality marker in MDS, and their share were 8.28, 10.7 and $6.66 \%$ towards SQI development, respectively. Since, $\mathrm{P}_{\mathrm{a}}$ has been accepted as the limiting factor in EZ soil due to $74.8 \%$ soil samples showed its deficiency $\left(<10 \mathrm{~kg} \mathrm{P} \mathrm{ha}^{-1}\right)$, but current $\mathrm{P}_{\mathrm{a}}$ levels in CZ $\left(27.8 \mathrm{~kg} \mathrm{ha}^{-1}\right)$ and WZ $(18.7 \mathrm{~kg} \mathrm{P}$ $\mathrm{ha}^{-1}$ ) are not in the deficiency range. Hence, greater $\mathrm{P}$ is required for cane growth notably in wherein excess aerial root occurs for their survival under water logging conditions (Tarafdar \& Claassen, 1988). Landon (1984) suggested that sugarcane is a moderate $\mathrm{P}$ demanding crops, but its deficiency occurs only if Olsen $\mathrm{P}$ levels $<7 \mathrm{ppm}$, whereas for $\mathrm{K}$, the critical value ranges from $78-125$ ppm (Filho, 1985). The values obtained 
under this study were above the critical levels both in CZ and WZ due to trash mulching practices are common in cane production system that return $\mathrm{P}$ and $\mathrm{K}$ back to soil, and thus mitigated exhaustion of these nutrients below critical levels. However, $\mathrm{P}$ and $\mathrm{K}$ levels below the critical levels in EZ soils might be excess P and K losses through surface-runoff in EZ soils (Khan and Qasim, 2008). Similarly, ALP retained as weighted variables in $\mathrm{CZ}$ and $\mathrm{WZ}$ despite having medium to high $\mathrm{P}$ levels as it played a vital role in enhancing $\mathrm{P}_{\mathrm{a}}$ by secreting phosphomonoesterases enzymes by enhancing microbial activity. Nakas et al. (1987) reported that soil bacteria, fungi and fauna responsible for secreting extracellular phosphatases due to their large combined biomass, high metabolic activity and short lifecycles. Variations of ALP towards SQI developments are related to management practices, changes in hydrothermal conditions, microbial activity and nutrient availability in soil. Olander \&Vitousek (2000) and Deng et al. (2017) attributed that high N fertilization accelerated phosphatase activity and $\mathrm{P}$ mobilization, since $\mathrm{N}$ is used as an essential nutrient for the synthesis of soil enzymes. $S_{a}$ was chosen as the representative of stability function for the MDS in each EZ, CZ and WZ as 43.3, 58.8 and $27.9 \%$ soil samples falls in low categories ( $<10 \mathrm{mg} \mathrm{kg}^{-1}$ soil), respectively. The $\mathrm{S}_{\mathrm{a}}$ contribution were 5.01, 5.67 and $7.06 \%$ towards the SQI in EZ, CZ and WZ soil, respectively indicated their importance in each cane producing zones. Contribution of $\mathrm{S}_{\mathrm{a}}$ was greater in WZ over CZ and EZ soil directly linked to more S availability in WZ soil. Soil available Zn was retained as MDS in WZ due to $47.5 \%$ soil samples falls under low Zn categories $\left(<0.6 \mathrm{mg} \mathrm{kg}^{-1}\right)$ along with higher factor loading value. Casarin et al. (2001) report that in low fertile soil, which are exploited for many years without Zn fertilization, the occurrence of its deficiency becomes more aggravated as sugarcane frequently exhibits "hidden hunger" a situation in which the symptoms do not appear visually (Orlando Filho et al., 2001). Thus, zinc fertilization mainly in Zn-deficient sugarcane grown soils might be important to maintain adequate Zn level for affording higher internodes, top growth, stalk length and cane yields (Alloway, 2008). BSR is the most used attributes as biological indicators of soil, since, it produces through decomposition of microbial biomass which is the most active living part of the SOM formed mainly by bacteria, fungi and actinomycetes (Kaschuk et al., 2009). Hence, BSR retained as soil quality indicators in CZ and WZ soils due to higher factor loading value in respected PCs. BSR contributed 5.11 and $6.42 \%$ towards the SQI development in CZ and WZ soils, respectively. The WZ soils had more BSR thereby producing more biomass, MBC and microbial activity (Galdos et al., 2009).

\subsection{Fertilizer recommendations}

Sugarcane monocropping over the decades deteriorated nutrient index and soil quality due to causing multinutrient deficiency occurs by imbalance fertilization. Hence, targeted yield equations (TYE) ensure balanced fertilization as doses of $\mathrm{N}, \mathrm{P}$ and $\mathrm{K}$ were applied on the basis of initial soil test value under the concept "Fertilizing the soil Vs Fertilizing the crop" proposed by Ramamurthy and Bajaj (1969). WZ soils needed greater amount of $\mathrm{N}$ than $\mathrm{EZ}$ and $\mathrm{CZ}$ for both plant and ratoon crop due to excess $\mathrm{N}$ mining from the decades resulted depleted soil $\mathrm{N}_{\mathrm{a}}$ might be due to mismatch between applied and removal of nitrogen (Shukla et al., 2009; Shukla et al., 2017). The greater P and K fertilizers required in plant and ratoon crops grown in EZ soils linked to lower $\mathrm{P}_{\mathrm{a}}$ and $\mathrm{K}_{\mathrm{a}}$ status caused through surface runoff (Zhao et al., 1988; Li et al., 2007a). However, lower or even negative $\mathrm{P}_{2} \mathrm{O}_{5}$ doses required in $\mathrm{CZ}$ and $\mathrm{WZ}$ soil due to high $\mathrm{P}_{\mathrm{a}}$ status occurs by applying excess $\mathrm{P}$ fertilizers. The lower $\mathrm{K}$ status in $\mathrm{EZ}$ soils (87.8\% soil sample deficient) liable to required more $\mathrm{K}_{2} \mathrm{O}$ for achieving $100 \mathrm{Mg}$ cane yield ha- ${ }^{-1}$ as it removed about $280 \mathrm{~kg} \mathrm{~K} \mathrm{ha}^{-1}$ against applied $60 \mathrm{~kg}$ $\mathrm{K}_{2} \mathrm{O}$ ha ${ }^{-1}$.

\section{CONCLUSION}

Sugarcane mono-cropping degraded SOC, $\mathrm{N}_{\mathrm{a}}, \mathrm{K}_{\mathrm{a}}, \mathrm{S}_{\mathrm{a}}$ and $\mathrm{Zn}$ across the cane producing zones, but enormity of soil degradation was more in EZ soils due to low-lying area induces multi-nutrient deficiency, and Fe and Mn content. As a result, lowest soil quality index and highest sensitivity index was in EZ than WZ and CZ. Reversely, CZ soils observed higher nutrient index and soil quality due to greater $\mathrm{N}_{\mathrm{a}}, \mathrm{P}_{\mathrm{a}}$ and $\mathrm{K}_{\mathrm{a}}$, TCF, FDA, ?-glucosidase, and urease activities. $\mathrm{N}_{\mathrm{a}}$, SOC, AZO and $\mathrm{S}_{\mathrm{a}}$ were the common limiting factors across the cane producing zones but, their contributions fluctuated towards SQI development owing to variation in edaphic factor under different cane producing zones. Since, wide variations existed between recommended 
doses of mineral fertilizers and targeted yield equations based fertilization. Hence, it will be better to cane growers, industry people and policy makers to advise balance nutrient management based on targeted yield equations for achieving higher sugarcane productivity, and improving nutrient index and soil quality. Over all, sugarcane mono-cropping over the decades degraded nutrient index, microbial activity, and soil quality index adversely due to imbalance fertilization. This may further increased if using improper management practices notably in low-lying areas.

\section{ACKNOWLEDGMENTS}

This research was supported by ICAR-Indian Institute of Sugarcane Research, Lucknow, India. The authors are grateful to the Director, ICAR-Indian Institute of Sugarcane Research, Lucknow for sanction of project and providing facilities. The assistance provided by technical staff during the conductance of experiments is duly acknowledged.

\section{References}

Alef, K. \& Nannipieri, P. (1995). Enzyme activities.Methods in Applied Soil Microbiology and Biochemistry. Published by Academic Press, Elsevier. (1995), Pages 311-373. https://doi.org/10.1016/B978-0125138406/50022-7.

Alemayehu, D. (2010). Sustainable Sugarcane Production in Ethiopia, Exploring Challenges and Opportunities. Biological Farming System Group. M.Sc. Thesis. Wageningen University, The Netherlands.

Alloway, B.J. (2008). Zinc in soil and crop nutrition. International Fertilizer Industry Association, and International Zinc Association.

Amara, D. M. K., Patil, P. L., Kamara, A. M. \& Saidu, D. H. (2017). Assessment of soil fertility status using nutrient index approach.Academia Journal of Agricultural Research , 5(2), 028-038. DOI: 10.15413/ajar.2017.0303.

Anderson, J. P. E. (1982). Soil respiration. In P. Al, R. H. Miller, \& D. R. Keeney (Eds.), Methods of soil analysis, part 2. American Society of Agronomy, Soil Science Society of American Journal (pp. 831-871). Madison, WI: Soil Science Society of America, Inc.

Bhaduri, D., Purakayastha, T., 2014. Long-term tillage, water and nutrient management in ricewheat cropping system: assessment and response of soil quality. Soil\& Tillage Research , 144, 83-95. DOI:10.1016/j.still.2014.07.007.

Bigott, A.F., Hoy, J.W., \& Fultz, L.M. (2019). Soil properties, microbial communities, and sugarcane yield in paired fields with short- or long-term sugarcane cultivation histories. Applied Soil Ecology , 142: 166-176. https://doi.org/10.1016/j.apsoil.2019. 04.027.

Black, E., Vidale, P.L.,Verhoef, A., Cuadra, S.V., Osborne, T., \& Van den Hoof, C. (2012). Cultivating C4 crops in a changing climate: sugarcane in Ghana. Environmental Research Letter, 7, 044027. https://doi.org/10.1088/1748-9326/7/4/044027.

Brady, N.C., \& Weil, R.R. (2000). Nature and Properties of Soils. Macmillan Publishing Company, New York, pp. 392-393.

Brejda, J. I., Moorman, T. B., Karlen, D. L., \& Dao, T.H. (2000). Identification of regional soil quality factors and indicators. I. Central and southern high plains. Soil Science Society of America Journa 1, 64, 2115-2124.https://pubag.nal.usda.gov/download /14295/PDF.

Brzezińska, M., Stepniewski, W., Stepniewska, Z., \&Przywara, G. (2001). Effect of Oxygen Deficiency On Soil Dehydrogenase Activity In a Pot Experiment With Triticale CV. Jago Vegetation. International Agrophysics , 15, 145149.

Carter, M. R. (2002). Soil quality for sustainable land management.Agronomy Journal , 94, 38-47. https://doi.org/10.2134/agronj2002.3800 
Casarin, V., Villa-Nova, V.S., \& Forli, F. (2001). Micro nutrientes em cana-deaçúcar. In: Marques, M.O. Mutton, M.A. Tópicos em tecnologia sucroalcooleira. 1.ed. Jaboticabal: FUNEP pp. 1-12.

Castioni, G.A., Cherubin, M.R., Menandro, L.M.S., Sanches, G.M., Bordonal, R. de O., Barbosa, L.C., Franco, H.C.J., \& Carvalho, J.L.N. (2018). Soil physical quality response to sugarcane straw removal in Brazil: a multi-approach assessment. Soil \& Tillage Research , 184, 301-309. https://doi.10.1016/j.still.2018.08.007.

Cherubin, M. R., Karlen, D.L., Cerri, C.E.P., Franco, A.L.C., Tormena, C.A., \& Davies, C.A., et al. (2016). Soil Quality Indexing Strategies for Evaluating Sugarcane Expansion in Brazil. PLoS ONE, 11(3): e0150860. doi:10.1371/journal.pone.0150860.

Chi, L., Mendoza-Vega, J., Huerta, E., \& Álvarez-Solís, J.D. (2017). Effect of long-term sugarcane (Saccharum Spp.) cultivation on chemical and physical properties of soils in Belize. Communications in Soil Science and Plant Analysis , 48, 7, 741-755, DOI: 10.1080/00103624.2016.1254794.

Cooperative Sugar, 2021. Published by National Federation of Cooperative Sugar Factories, LTD, 52 (5), $48-56$.

de Freitas, L., Filho, M.V.M., \& Casagrande, J.C. et al. (2018). Soil quality indicator of oxisols grown with sugarcane and native forest in northeastern São Paulo state, Brazil. Environmental Earth Science, 77, 642. https://doi.org/10.1007/s12665-018-7830-7.

Deng, Q., Hui, D., Dennis, S., \& Reddy, K.C. (2017). Responses of terrestrial ecosystem phosphorus cycling to nitrogen addition: a meta-analysis. Glob Ecology and Biogeography, 26(6), 713-728. https://doi.org/10.1111/geb.12576.

Ditxler, C.A., \& Tugel, A.J. (2002). Soil quality field tools: experiences of USDA-NRCS soil quality institute. Agronomy Journal , 94, 33. http://dx.doi.org/10.2134 /agronj 2002. 0033.

Doran, J.W., \& Parkin, T.B. (1994a). Defining soil quality for a sustainable environment. SSSA Special Pub. 34. Soil Sci. Soc. Am., Madison, Wisconsin, U.S.A., pp. 3-21. https://doi.org/10.2136/sssaspecpub35.c1

Esmailpour A., Hassanzadehdelouei M., \& Madani A. (2013). Impact of livestock manure, nitrogen and biofertilizer (Azotobacter ) on yield and yield components wheat (Triticum Aestivum L.) Cercetari Agronomice in Moldova, 46(2):5-15. http://dx.doi. 10.2478/v10298-012-0079-5.

FAO (2019). The agricultural production indices. FAOSTAT, Food and Agricultural Organisation of the United Nations (FAO). Online, Available http://faostat.fao.org/ (Accessed on April, 2019).

Filho, J. O. (1985). Potassium nutrition of sugarcane. In: Munson RE (eds.) Potassium in Agriculture. American Society of Agronomy, Madison, Wisconsin, USA, pp: 1045-1076. https://doi.org/10.2134/1985.potassium.c44

Galdos, M.V., Cerri, C.C., \& Cerri, C.E.P. (2009). Soil carbon stocks under burned and unburned sugarcane in Brazil. Geoderma. 153:347-352.http://dx.doi.org/10.1016/j. geoderma. 2009.08.025.

Gong, L., Ran, Q., He, G., \& Tiyip, T. (2015). A soil quality assessment under different land use types in Keriya river basin, Southern Xinjiang, China. Soil \& Tillage Research , 146, 223-229. DOI : 10.1016/j.still.2014.11.001.

Graham, M.H., \& Haynes, R.J. (2005). Organic matter accumulation and fertilizers? Induced acidification interact to affect soil microbial and enzymatic activity on long term sugarcane management experiment.Biology E Fertility of Soils , 41, 249-256. https://doi.org/10.1007/s00374-005-0830-2

Gregorich, E.G., Carter, M. R., Angers, D. A., Monreal, C. M., \& Eliert, B. H. (1994). Towards a minimum data set to assess soil organic matter in agricultural soils. Canadian Journal of Soil Science , 74, 367-385. https://doi.org/10.4141/cjss94-051. 
Hart, M. R., Quin, B. F., \& Nguyen, M. L. (2004). Phosphorus runoff from agricultural land and direct fertilizer effects: a review. Journal of Environmental Quality, 536 1954-1972. https://doi.org/10.2134/jeq2004.1954

Hartemink, A.E. (1998). Soil chemical and physical properties as indicators of sustainable land management under sugar cane in Papua New Guinea.Geoderma , 85(4), 283-306.DOI: 10.1016/S0016-7061(98)00048-2.

Hartemink, A.E. (2008). Sugarcane for bioethanol: soil and environmental issues. Advances in Agronomy , 99, 125-182. https://doi.org/10.1016/S0065-2113(08)00403-3

Hidaka, Tetsushi, \&Karim, M. A. (2007). Flooding tolerance of sugarcane in relation to growth and root structure. South Pacific Studies , 28(1), 9-22. http://hdl.handle.net/ 10232/9538

Holt, J.A., \& Mayer, R.J. (1998). Changes in microbial biomass and protease activities of soil associated with long-term sugar cane monoculture. Biology \& Fertility of Soil, 27, 127-131. https://doi.org/10.1007/s003740050410

Jackson, M.L. (1973). Soil Chemical Analysis. New Delhi, India: Prentice Hall of India Pvt., Ltd.

Jenkinson, D.S., \& Powlson, D.S. (1976). The effects of biocidal treatments on metabolism in soil. V. A method for measuring soil biomass. Biology $\&$ Fertility of Soil, 8, 209-213. https://doi.org/10.1016/00380717(76)90005-5.

Jenny, H. (1941). Factors of Soil Formation. McGraw-Hill, New York.

Kang, G., Beri, V., Sidhu, B., \& Rupela, O. (2005). A new index to assess soil quality and sustainability of wheat-based cropping systems.Biology \& Fertility of Soil, 41, 389-398. https://doi.org /10.1007/s00374005-0857-4

Kaschuk, G., Alberton, O., \& Hungria, M. (2009). Three decades of soil microbial biomass studies in Brazilian ecosystems: Lessons learned about soil quality and indications for improving sustainability. Biology E Fertility of Soil, 42:1-13. http://dx.doi.org /10.1016 /j.soil bio.2009.08.020.

Khan, M.J., \& Qasim, M. (2008). Integrated use of boiler ash as organic fertilizer and soil conditioner with NPK in calcareous soil. Songklanakarin Journal of Science \&Technology, 30, 281-289.

Kingston, G. (2014). "Mineral nutrition of sugarcane," in Sugarcane: Physiology, Kingston, G. (2014). "Mineral nutrition of sugarcane," in Sugarcane: Physiology, John Wiley \& Sons), 85-120. https://doi.org/10.1002/9781118771280.ch5

Kizilkaya, R. (2009). Nitrogen fixation capacity of Azotobacter spp. strains isolated from soils in different ecosystems and relationship between them and the microbiological properties of soils. Journal of Environmental Biology , 31(1), 73-82.

Krishnakant, Tripathi, S.P., \& Meena, M. (2015). Cost of cultivation of sugarcane crop in Meerut district of Uttar Pradesh. International Journal of Forestry Crop Improvement , 6 (1), 41-48. DOI: 10.15740/HAS/IJFCI/6.1/41-48

Landell, M.G.A., Prado, H., Vasconcelos, A.C.M., Perecin, D., Rossetto, R., Bidoia, M.A.P., Silva, M.A., \& Xavier, M.A. (2003). Oxisol subsurface chemical attributes related to sugarcane productivity.Scientia Agricola, 60, 741-745.

Landon, J.R. (1984). Booker Tropical Soil Manual: A hand book for soil survey and agricultural land evaluation in the tropics. Longman. New York, USA.

Larson, W.E., \& Pierce, F.J. (1994). The dynamics of soil quality as a measure of sustainable management.In: Doran, J.W., Coleman,D.C., Bezdicek, D.F., Stewart, B.A. (Eds.), Defining Soil Quality for a Sustainable Environment, Madison, W.I.. Soil Science Society of America, 35, pp. 37-52(special publication).https://doi.org/10.2136/ sssaspecpub35.c3 
Li, C.L., He, Y.Q., Wang, Y.L., \& Liu, X.L. (2007a). Effect of N, P and K fertilizer application on rice grain yield in red paddy soil. Chinese Journal of Rice Science, 21 (2), 179-184 (in Chinese).

Li, X., Mu, Y., Cheng, Y., Liu, X., \& Nian, H. (2013). Effects of intercropping sugarcane and soybean on growth, rhizosphere soil microbes, nitrogen and phosphorus availability. Acta Physiologiae Plantarum 35, 1113-1119. https://doi.org/10.1007/s11738-012-1148-y.

Lin, W.X., Chen, T., \& Zhou, M.M. (2012). New dimensions in agroecology. Chinese Journal of EcoAgriculture, 20, 253-264. 10.3724/SP.J.1011.2012.00253

Lisboa, C.C., Butterbach-Bahl, K., Mauder, M., \& Kiese, R. (2011). Bioethanol production from sugarcane and emissions of greenhouse gases - known and unknowns. GCB Bioenerg , 3, 277-292. doi: 10.1111/j.17571707.2011.01095.x

Liu, Z., Zhou, W., Lv, J., He, P., Liang, G., \& Jin, H. (2015). A simple evaluation of soil quality of waterlogged purple paddy soils with different productivities. PLoS One, 10, e0127690. https://doi.org/10.1371/journal.pone.0127690.

Macedo, I.C. (2007). Sugar cane's Energy. Twelve studies on Brazilian sugar cane agribusiness and its sustainability, UNICA (233 p).

Magarey, R.C. (1996). Microbiological aspects of sugarcane yield decline. Australian Journal of Agricultural Research , 47, 307-322. https://doi.org/10.1071/AR9960307

Malavolta, E., Vitti, G.C., \& Oliveira, A.S. (1997). Avaliacao do estado nutricional das plantas: principios e aplicacoes. 2.ed. Piracicaba: Potafos. 319 p.

Martin, J.P. (1950). Use of acid rose Bengal and streptomycin in the plate method for estimating soil fungi. Soil Science, 69, 215-232. http://dx.doi.org/10.1097/000106 94-195003000-00006

Masto, R. E. Chhonkar, P. K., Singh, D., \& Patra, A. K. (2008). "Alternative soil quality indices for evaluating the effect of intensive cropping, fertilisation and manuring for 31 years in the semi-arid soils of India. Environmental Monitoring and Assessment, 136, 419-435. https://doi.org/10.1007/s10661-007$9697-\mathrm{z}$

Masto, R.E., Chhonkar, P.K., Singh, D., \& Patra, A.K. (2007). Soil quality response to long-term nutrient and crop management on a semi-arid Inceptisol. Agriculture Ecosystem \& Environment , 118, 130-142. https://doi.org/10.1016/j.agee.2006.05.008

Meena, V. S., Maurya, B.R., Meena, R.S., Meena, S.K., Singh, N, P., Malik, V.K., \& Kumar, Jat, L.K. (2014). Microbial dynamics as influenced by concentrate manure and inorganic fertilizer in alluvium soil of Varanasi, India. African Journal of Microbiological Research , 8 , 257-263. https://doi.org/10.5897/AJMR2013.5448.

Mello, F.F.C., Cerri, C.E.P., Davies, C.A., Holbrook, N.M., Paustian, K., \& Maia, S.M.F. (2014). Payback time for soil carbon and sugar-cane ethanol. Nat. Climate Change, 4, 605-609. https://doi.org/10.1038/nclimate2239

Moscatelli, M. C., Di Tizio, A., Marinari, S., \& Grego, S. (2007). Microbial indicators related to soil carbon in Mediterranean land use systems. Soil \& Tillage Research , 97, 51-59.

Nakas, J.P., Gould, W.D., \& Klein, D.A. (1987). Origin and expression of phosphatase activity in a semi-arid grassland soil. Soil Biology \& Biochemistry, 19, 13-18. https://doi.org/10.1016/0038-0717(87)90118-0

Naranjo, J.F., Salgado-Garcia, S., Lagunes-Espinoza, L.C., Carrillo-Avila, E., \& Palma-Lopez, D.J. (2006). Changes in the properties of a Mexican fluvisol following 30 years of sugarcane cultivation. Soil ESTillage Research , 88, 160-167. https://doi.org/10.1016 /j.still.2005.05.006

Nortcliff, S. (2002). Standardization of soil quality attributes.Agriculture Ecosystem \& Environment , 88, 161-168. https://doi.org/10.1016/S0167-8809(01)00253-5 
Olander, L.P., \& Vitousek, P.M. (2000). Regulation of soil phosphatase and chitinase activity by N and P availability. Biogeochemistry 49: 175-191.https://doi.org/10.1023/A:1006 316117817.

Orlando Filho, J., Rosseto, R., \& Casagrande, A.A. (2001). Cana-de-acucar. In: Ferreira ME ed. Micronutrientes e elementos toxicos na agricultura. 1.ed. Jaboticabal: CNPq/FAPESP/Potafos. pp. 355-373.

Otto, R., Mariano, E., Mulvaney, R.L., Khan, S.A., Boschiero, B.N., Tenelli, S., \&Trivelin, P.C.O. (2017). Effect of previous soil management on sugarcane response to nitrogen fertilization.Scientia Agrocola DOI: http://dx.doi.org/10.1590/1678-992X-2017-0147.

Pankhurst, C.E., Magarey, R.C., Stirling, G.R., Blair, B.L., Bell, M.J., \& Garside, A.L. (2003). Management practices to improve soil health and reduce the effects of detrimental soil biota associated with yield decline of sugarcane in Queensland. Soil ET Tillage Research,72:125-137. https://doi.org/10.1016/S01671987(03)00083-7

Parkinson, D., Gray, T. R. G., \& Williams, S. T. (1971). Methods for Studying the Ecology of Soil Microorganisms. International Biological Programme Handbook 19. Oxford, UK: Blackwell Scientist Publications. https://doi.org/10.1002/jpln.19721320316.

Pavanasasivam, V., \& Axley, J.H. (1980). Influence of flooding on the availability of soil Zn. Communication in Soil Science Plant Analysis , 11, 163-174. https://doi.org/10.1080 /00103628009367025

Qi, Y., Darilek, J.L., Huang, B., Zhao, Y., Sun, W., \& Gu, Z. (2009). Evaluating soil quality indices in an agricultural region of Jiangsu Province. China. Geoderma , 149, 325-334. https://doi.org/10.1016/j.geoderma.2008.12.015

Rahman, F., \& Bee, N. (2019). Trends and Pattern of Sugarcane Production in Shahjahanpur District, Uttar Pradesh: A Geographical Analysis. Economic Affairs , 64 (3), 537-545. DOI: 10.30954/0424-2513.3.2019.9.

Rahmanipour, F., Marzaioli, R., Bahrami, H.A., Fereidouni, Z., \& Bandarabadi, S.R. (2014). Assessment of soil quality indices in agricultural lands of Qazvin Province, Iran. Ecological Indicator , 40, 19-26. https://doi.org/10.1016/j.ecolind.2013.12.003

Ramamurthy, B., \& Bajaj, J.C. (1969). Available nitrogen, phosphorus and potassium status of Indian soils. Fertilizer News, 14, 25-36.

Rietz, D.N., \& Haynes, R.J. (2003). Effects of irrigation induced salinity and sodicity on soil microbial activity. Soil Biology $\&$ Biochemistry , 35, 845-854. https://doi.org/10.1016/S0038-0717(03)00125-1

Salazar, S., Sanchez, L.E., Alvarez, J., Valverde, A., Galindo, P., Igual, J.M., Peix, A., \& Santa-Regina, I. (2011). Correlation among soil enzyme activities under different forest system management practices.Ecological Engineering,37 (8), 1123-1131. https://doi. org/10.1016/j.ecoleng.2011.02.007

Satiro, L.S., Cherubin, M.R., Safanelli, J.L., Lisboa, I.P., da Rocha Junior, P.R., Cerri, C.E.P., \& Cerri, C.C. (2017). Sugarcane straw removal effects on Ultisols and Oxisols in southcentral Brazil.Geoderma, 11, 86-95. https://doi.org/10.1016/j.geodrs.2017. 10.005

Shukla, A.K., Behera, S.K., Singh, V.K., Prakash, C., Sachan, A.K., Dhaliwal, S.S., Srivastava, P.C., Pachauri, S.P., Tripathi, A., Pathak, J., Nayak, A.K., Kumar, A., Tripathi, R., Dwivedi, B.S., Datta, S.P., Meena, M.C., Das, S., \& Trivedi, V. (2020). Pre-monsoon spatial distribution of availble micronutrients and sulphur in surface soils and their management zones in Indian Indo-Ganagetic Plains. PloS ONE , 15(6), e0234053. https://doi.org/10.1371/journal.pone.0234053

Shukla, S. K., \& Lal, M. (2004). Effect of sulphur on productivity and quality of sugarcane plant and ratoon crops grown in sugarcane (plant)- ratoon- wheat (Triticum aestivum ) system on IGP alluvial soils.Indian Journal of Agronomy , 49(1), 26-27.

Shukla, S. K., Sharma, L., Awasthi, S. K., \& Pathak, A. D. (2017). Sugarcane in India: Package of practices for different agro-climatic zones, pp 1-64. 
Shukla, S.K., Yadav, R.L., Singh, P.N., \& Singh, I. (2009). Potassium Nutrition for Improving Stubble Bud Sprouting, Dry Matter Partitioning, Nutrient Uptake and Winter Initiated Sugarcane (Saccharum spp. hybrid complex) Ratoon Yield. European Journal of Agronomy , 30(1), 27-33. https://doi.org/10.1016/j.eja.2008.06.005

Singh, S. P., \& Setter, T. L. (2017). Effect of waterlogging on element concentrations, growth and yield of wheat varieties under farmer's sodic field conditions. National Academy of Sciences, India, Section B : Biological Sciences , 87, 513-520. https://doi. org/10.1007/ s40011-015-0607-9

Souza, R.A., Telles, T.S., Machado, W., Hungria, M., Filho, J.T.,\& de Fatima Guimaraes, M. (2012). Effects of sugarcane harvesting with burning on the chemical and microbiolog-ical properties of the soil.Agriculture Ecosystem \& Environment, 155, 1-6. https://doi. org/10.1016/j.agee.2012.03.012

SPSS, 2001. Statistical Package. Version 11.0 for Windows. SPSS Inc., Chicago, IL.

Stirling, G.R., Moody, P.W., \& Stirling, A.M. (2010). The impact of an improved sugarcane farming system on chemical, biochemical and biological properties associated with soil health. Applied Soil Ecology , 46, 470-477. https://doi.org/10.1016/j.apsoil.2010. 08.015

Subba Rao, 1977. Soil Microorganisms and Plant growth, Oxford and IBH Publishing Co., India.

Tarafdar, J.C., \& Claassen, N. (1988). Organic phosphorus compounds as a phosphorus source for higher plants through the activity of phosphatase produced by plant roots and microorganisms. Biology $\& 3$ Fertility of Soils , 5, 308-312. https://doi.org/10.1007/BF00 262137

United States Department of Agriculture (USDA) (1996). Soil survey laboratory methods manual: Washington D.C. U.S. Department of Agriculture, National Resources Conservation Services, National Soil Survey Centre, Soil Survey Investigations, Report No. 42.

Upreti, P., \& Singh, A. (2017). An Economic Analysis of Sugarcane Cultivation and its Productivity in Major Sugar Producing States of Uttar Pradesh and Maharashtra. Economic Affairs, 62(4), 711. 10.5958/09764666.2017.00087.0.

Vance, E.D., Brookes, P.C., \& Jenkinson, D.S. (1987). An extraction method for measuring soil microbial biomass C. Biology \&3 Fertility of Soils, 19, 703-707. https://doi.org/10.1016/00 38-0717(87)90052-6.

Vinhal-Freitas, I.C., Correa, G.F., Wendling, B., Bobuľská, L., \& Ferreira, A.S. (2017). Soil textural class plays a major role in evaluating the effects of land use on soil quality indicators.Ecological Indicator , 74, 182-190. https://doi.org/10.1016/j.ecolind.2016.11.020

Wani S.A., Chand S., Wani M.A., Ramzan M., \& Hakeem K.R. (2016). Azotobacter chroococcum - A Potential Biofertilizer in Agriculture: An Overview. In: Hakeem K., Akhtar J., Sabir M. (eds.) Soil Science: Agricultural and Environmental Prospectives . Springer,Cham. https://doi.org/10.1007/978-3-319-34451-5_15

Yadav, R.L., Suman, A., Prasad, S.R., \& Prakash, O. (2009). Effect of Gluconacetobacter diazotrophicus and Trichoderma viride on soil health, yield and N-economy of sugarcane cultivation under subtropical climatic conditions of India. European Journal of Agronomy, 30, 296-303. https://doi.org/10.1016/j.eja.2009.01.002

Yue-Ju, X., Shu-Guang, L., Yue-Ming, H., \& Jing-Feng, Y. (2010). Soil quality assessment using weighted fuzzy association rules.Pedosphere , 20, 334-341. https://doi.org/10. 1016/S1002-0160(10)60022-7

Zhang, T., Wan, S., Kang, Y., \& Feng, H. (2014). Urease activity and its relationships to soil physiochemical properties in a highly saline-sodic soil. Journal of Soil Science \&3 Plant Nutrition , 14(2), 304315.http://dx.doi.org/10.4067/S0718-95162014005000025.

Zhao, Q.G., Xie, W.M., He, X.J., \& Wang, M.Z. (1988). Red Soil in Jiangxi Province. Jiangxi Science and Technology Press, Nanchang, China (in Chinese). 


\section{Hosted file}

Fig. 1..docx available at https://authorea.com/users/333549/articles/542402-nutrient-indexmicrobial-activity-and-soil-quality-depleted-under-sugarcane-mono-sequencing-in-indiansubtropics

\section{Hosted file}

Table 1.docx available at https://authorea.com/users/333549/articles/542402-nutrient-indexmicrobial-activity-and-soil-quality-depleted-under-sugarcane-mono-sequencing-in-indiansubtropics

\section{Hosted file}

Table 2.docx available at https://authorea.com/users/333549/articles/542402-nutrient-indexmicrobial-activity-and-soil-quality-depleted-under-sugarcane-mono-sequencing-in-indiansubtropics

\section{Hosted file}

Table 3.docx available at https://authorea.com/users/333549/articles/542402-nutrient-indexmicrobial-activity-and-soil-quality-depleted-under-sugarcane-mono-sequencing-in-indiansubtropics

\section{Hosted file}

Table 4..docx available at https://authorea.com/users/333549/articles/542402-nutrient-indexmicrobial-activity-and-soil-quality-depleted-under-sugarcane-mono-sequencing-in-indiansubtropics

\section{Hosted file}

Table 5.docx available at https://authorea.com/users/333549/articles/542402-nutrient-indexmicrobial-activity-and-soil-quality-depleted-under-sugarcane-mono-sequencing-in-indiansubtropics

\section{Hosted file}

Table 6..docx available at https://authorea.com/users/333549/articles/542402-nutrient-indexmicrobial-activity-and-soil-quality-depleted-under-sugarcane-mono-sequencing-in-indiansubtropics

\section{Hosted file}

Table 7..docx available at https://authorea.com/users/333549/articles/542402-nutrient-indexmicrobial-activity-and-soil-quality-depleted-under-sugarcane-mono-sequencing-in-indiansubtropics

\section{Hosted file}

Table 8..docx available at https://authorea.com/users/333549/articles/542402-nutrient-indexmicrobial-activity-and-soil-quality-depleted-under-sugarcane-mono-sequencing-in-indiansubtropics 